\title{
Earthworm assemblages in different intensity of agricultural uses and their relation to edaphic variables
}

Liliana B Falco, Rosana V Sandler, Fernando R Momo, César A Di Ciocco, Leonardo A Saravia, Carlos E Coviella

The objective of this study was to relate earthworm assemblage structure with three different soil use intensities, and to indentify the physical, chemical, and microbiological soil variables that are associated to the observed differences. Three soil uses were evaluated: 1- Fifty year old naturalized grasslands, low use intensity; 2- Recent agricultural fields, intermediate use intensity, and 3- Fifty year old intensive agricultural fields, high use intensity. Three different sites for each soil use were evaluated from winter 2008 through summer 2011. Nine earthworm species were identified across all sampling sites. The sites shared five species: the native Microscolex dubius, and the introduced Aporrectodea caliginosa, A. rosea, Octalasion cyaneum, and O. lacteum, but they differed in relative abundance by soil use. The results show that the earthworm community structure is linked to and modulated by soil properties. Both species abundance and diversity showed significant differences depending on soil use intensity. A principal component analysis showed that species composition is closely related to the environmental variability. The ratio of native to exotic species was significantly lower in the intensive agricultural system when compared to the other two, lower disturbance systems. Microscolex dubius abundance was related to naturalized grasslands along with soil $\mathrm{Ca}, \mathrm{pH}$, mechanical resistance, and microbial respiration. Aporrectodea caliginosa abundance was related to high $\mathrm{K}$ levels, low enzymatic activity, slightly low $\mathrm{pH}$, low $\mathrm{Ca}$, and appeared related to the highly disturbed environment. Eukerria stagnalis and Aporrectodea rosea, commonly found in the recent agricultural system, were related to high soil moisture condition, low $\mathrm{pH}$, low $\mathrm{Ca}$ and low enzymatic activity. These results show that earthworm assemblages can be good indicators of soil use intensities. In particular, Microscolex dubius, Aporrectodea caliginosa, and Aporrectodea rosea, showed different temporal patterns and species associations, due to the changes in soil properties attributable to soil use intensity, defined as the amount and type of agricultural operations. 
Corresponding author:

Liliana B. Falco

Departamento de Ciencias Básicas

Universidad Nacional de Luján, Argentina

Av. Constitución y Ruta 5, CC 221 (6700) Luján. Buenos Aires, Argentina

Voice: 54-2323-420380

Mail: falcoliliana@gmail.com

\section{Abstract}

The objective of this study was to relate earthworm assemblage structure with three different soil use intensities, and to indentify the physical, chemical, and microbiological soil variables that are associated to the observed differences. Three soil uses were evaluated: 1- Fifty year old naturalized grasslands, low use intensity; 2- Recent agricultural fields, intermediate use intensity, and 3- Fifty year old intensive agricultural fields, high use intensity. Three different sites for each soil use were evaluated from winter 2008 through summer 2011. Nine earthworm species were identified across all sampling sites. The sites shared five species: the native Microscolex dubius, and the introduced Aporrectodea caliginosa, A. rosea, Octalasion cyaneum, and O. lacteum, but they differed in relative abundance by soil use. The results show that the earthworm community structure is linked to and modulated by soil properties. Both species abundance and diversity showed significant differences depending on soil use intensity. A principal component analysis showed that species composition is closely related to the environmental variability. The ratio of native to exotic species was significantly lower in the intensive agricultural system when compared to the other two, lower disturbance systems. Microscolex dubius abundance was related to naturalized grasslands along with soil $\mathrm{Ca}, \mathrm{pH}$, mechanical resistance, and microbial respiration. Aporrectodea caliginosa abundance was related to high $\mathrm{K}$ levels, low enzymatic activity, slightly low $\mathrm{pH}$, low $\mathrm{Ca}$, and appeared related to the highly disturbed environment. Eukerria stagnalis and Aporrectodea rosea, commonly found in the recent agricultural system, were related to high soil moisture condition, low $\mathrm{pH}$, low $\mathrm{Ca}$ and low enzymatic activity. These results show that earthworm assemblages can be good indicators of soil use intensities. In particular, Microscolex dubius, Aporrectodea caliginosa, and Aporrectodea rosea, showed different temporal patterns and species associations, due to the changes in soil properties attributable to soil use intensity, defined as the amount and type of agricultural operations.

Keywords: soil ecology, soil use intensity, earthworms, bioindicator, farming systems 


\section{1. Introduction}

45 The organisms living in the soil, collectively known as soil biota, play a crucial role in regulating 46 processes like water infiltration and storage, decomposition and nutrient cycling, humus formation, 47 nutrient transformation and transport; moreover, they stimulate the symbiotic activity in the soil, 48 improve the organic matter storage, and prevent erosion (Coleman \& Crossley, 1996; Lavelle et al., 49 2006).

50 Several of the ecosystem services provided by soil depend on the community of soil invertebrates 51 (Lavelle et al., 2006), and earthworms are one of the most common components of edaphic 52 communities. Earthworms are considered ecosystem engineers because they improve decomposition 53 processes and nutrient cycling (Lavelle et al., 1997; Six et al., 2004) and have a strong effect on the 54 soils' hydraulic properties (Lee, 1985; Edwards \& Bohlen, 1996; Lavelle \& Spain, 2001; Lavelle et al., 55 2006; Johnson-Maynard, Umiker, \& Guy, 2007; Jouquet et al., 2008). As key detritivores, earthworms 56 are essential for soil nutrient recycling, and maintenance of soil structure (Dennis et al, 2012).

57 The most important factors limiting earthworm populations are food supply, moisture, temperature, and

58 the physical and chemical characteristics of the soil such as $\mathrm{pH}$, organic matter and macronutrients 59 content (Satchell, 1967; Lee, 1985; Curry, 2004). Earthworm populations are also affected by the direct 60 and indirect effects related to the type and extension of the vegetation cover (Mather \& Christensen, 61 1988; Falco \& Momo, 1995). Due to the strong relation between earthworms and soils (Paoletti et al, 62 1998), modern agricultural practices can modify the physical and chemical soil environment thus 63 modulating changes in abundance and composition of earthworm communities (Curry, Byrne \& 64 Schmidt, 2002). In this regard, Dale \& Polasky (2007) indicate that in agricultural systems, changes in 65 land cover are the direct result of management practices. Moreover, the use of pesticides and herbicides 66 in intensive agricultural systems is known to affect earthworms at different levels, from gene 67 expression and physiology, to the individual, population, and community structure (Pelosi et al, 2014, 68 Santadino, Coviella, \& Momo, 2014). In a study encompassing five different land use intensities in 69 Colombia, Feijoo et al (2011) found that high use intensity led to a loss of native species. Furthermore, 70 the use of heavy machinery prevents these native species from re-colonizing due to soil compaction.

71 Therefore, when changes occur in agricultural practices, earthworm assemblages are able to respond to 72 the ensuing changes in the soil's physical properties and environmental conditions (Lavelle et al, 1997; 73 Johnson-Maynard, Umiker, \& Guy, 2007). 
74 Since earthworm abundance and distribution are strongly influenced by the environmental conditions

75 and the ecological status of the system (Paoletti, 1998, Falco \& Momo, 2010, Pelosi, 2015), the

76 earthworm community structure can be successfully used as a biological indicator of soil conditions

77 (Paoletti, 1999, Momo, Falco, \& Craig, 2003). Guéi \& Tondoh (2012) found that earthworms can be

78 used to monitor land-use types with different levels of soil quality.

79 The use of bioindicators has the advantage of providing historical and functional information about

80 soils. The earthworm community structure integrates this information on soil conditions both in space

81 and time and provides indications of the soil's ecological state.

82 In this context, the objectives of this study were: 1) To assess the earthworm community structure 83 under three different soil use intensities: Fifty years old intensive agriculture, two years old recent 84 agriculture, and naturalized grasslands. 2) To identify the physical, chemical, and microbiological 85 variables related to the different soil use intensities affecting the earthworm community structure. 3) To 86 detect which earthworm species are typical of each set of soil conditions as affected by use intensity.

\section{Materials and Methods}

\section{$89 \quad 2.1$ Sampling sites}

90 This study was performed in the rolling pampas within the Argentine pampas, a wide plain with more

91 than 52 million hectares $\left(520.000 \mathrm{~km}^{2}\right)$ of land suitable for cattle production and cropping (Viglizzo et

92 al, 2004). It is one of the largest and most productive agricultural regions in the world.

93 Agricultural systems based on crop-crop and crop-pasture rotations under grazing conditions have

94 been very common in the region for over a century until the 1980s. The adoption of conservative

95 tillage and no-till practices has significantly increased during the 1980s and 1990s. Although

96 pesticides were extensively used since the 1960s, crops and pasture fertilization increased noticeably

97 only during the 1990s (Viglizzo et al, 2003). The expansion of the land area used for annual crops

98 means that the pampean ecosystem is currently under an intense disturbance regime (Navarrete et al, 99 2009).

100 The selected study sites are located in central Argentina, on Argiudolls soils?, (Mollisols, Typic 101 Argiudolls (USDA, 2010)). The study sites were privately owned fields located in Navarro, Buenos 


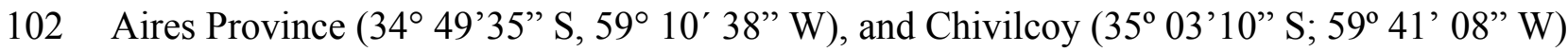

103 approximately 75 and $150 \mathrm{~km}$ west of Buenos Aires City, respectively (Fig. 1).

104 The weather regime in this region is temperate humid, with a mean annual rainfall around $1000 \mathrm{~mm}$.

105 The mean annual temperature is $17^{\circ} \mathrm{C}$. Phytogeographycally, it is within the neotropical region, 106 oriental district of the Pampean Province, and the dominant vegetation is a gramineous steppe (Cabrera 107 \& Willink, 1973).

\section{$109 \quad 2.2$ Land use intensity in the selected sites}

110 The analyzed systems differed only in their use intensity, as defined by the amount and type of

111 agricultural operations, such as tillage, pesticide use, rotation, fertilization, and harvesting. Samplings

112 were carried out on three different types of soil uses (agro-ecosystems) which represent three different 113 levels of disturbance of the same Argiudoll. These are:

114 High disturbance agro-ecosystem: Intensive agricultural system (AG); sites with 50 years of

115 continuous intensive agricultural practices, under a regular corn-wheat-soybean rotation, currently 116 under no-tillage, and chemical weed controls are used. During cropping season, heavy machinery is 117 used and insecticides, herbicides, and fertilizers are applied several times a year.

118 Intermediate disturbance agro-ecosystem: Recent agricultural system (RA); cattle-grazing sites that 119 were under direct grazing for 40 years. Originally managed under direct grazing, these sites moved to 120 bale production (oat, maize, and sorghum) two years before the start of this study.

121 Low disturbance agro-ecosystem: Naturalized grasslands (NG); sites with no significant anthropic 122 impact during the last 50 years.

123 Nine observation fields (three replicates for each one of the three agricultural systems) were evaluated.

124 Replicates were separated from each other by at least several hundred meters to a few kilometers. At 125 each site, five samples were taken every three months for a period of two years.

126 At each sampling date, five random samples were taken 25 meters apart from each other per each 127 replicate (3) and treatment (3). Thus, a total of 45 samples were taken per sampling date. The size of 128 each sample was of $25 \times 25 \times 25 \mathrm{~cm}$. 
129 The measured environmental variables were bulk density (BD), mechanical resistance (MR), 130 gravimetric moisture content (w), electrical conductivity (EC), organic mater (OM), $\mathrm{pH}$, total $\mathrm{N}$, total $131 \mathrm{P}$, exchangeable $\mathrm{Ca}$, exchangeable $\mathrm{Mg}$, exchangeable $\mathrm{K}$, and exchangeable $\mathrm{Na}$. To characterize the 132 sites, microbiological activity was assessed through soil respiration and free nitrogen-fixing bacteria 133 activity (Nitrogenase Acetylene Reduction Activity, ARA). Methods used for chemical and physical 134 analyses are shown in Table 1.

135 Earthworm extraction from the soil samples was performed by handsorting. Earthworms were 136 preserved with soil until identification in the laboratory. Later they were fixed and preserved in 137 alcohol- formalin - glycerin, following Righi (1979), and identified by external morphology using keys 138 from Righi (1979) and Reynolds (Reynolds, 1996). Clitelated individuals were identified to species 139 level and pre-clitelated ones to genus. At each site, earthworm taxonomic composition and population 140 density were measured. Earthworm communities were characterized at each soil use intensity by 141 population density, species richness both observed and estimated using the Chao index (Magurran, 142 2004), and diversity using the Shannon index (Zar, 1999).

143 The Chao index was calculated as:

$$
\hat{\mathrm{S}}=\mathrm{S}_{\mathrm{obs}}+\left(\mathrm{a}^{2} / 2 \mathrm{~b}\right)
$$

145 where:

146 Ŝ: Species richness estimate

$147 \mathrm{~S}_{\mathrm{obs}}:$ Observed species richness

148 a: Number of species found in only one sample, and

149 b: Number of species found in only two samples.

151 The Shannon index $\left(\mathrm{H}^{\prime}\right)$ was calculated as:

153 where:

$p_{i}$ : Number of individuals belonging to the species i / total number of individuals. 
$155 \quad 2.3$ Statistical analyses

156 Due to the non-normal distributions of the physical and chemical data, Kruskall-Wallis ANOVA tests

157 were carried out to compare variables between treatments. The Shannon index comparisons were

158 performed using ANOVA.

159 The relationship between environmental variables and earthworm species abundances was analyzed by 160 means of a principal component analysis (PCA) using abundances. Prior to analysis, the species

161 abundances data were transformed using the Hellinger distances (Legendre \& Gallagher 2001) in order

162 to preserve the distances among samples. To calculate the Hellinger distances, the abundances are first

163 divided by the sample total, the result is square root transformed, then Euclidian distances are

164 computed. As a result, Hellinger distances are scalar measurements of the divergence in the

165 distribution of samples. These distances are then used in the PCA. Physical and chemical variables

166 were then fitted into the ordination space described by the first two principal components of the

167 earthworm data by projecting biplot vectors. The statistical significance of the environmental variables

168 is based on random permutations of the data and P-values were adjusted by a sequential multiple test

169 procedure of Hommel (1988). The ordination analysis and vector fitting were produced using the R

170 statistical language (R Core team, 2012) and the Vegan package (Oksanen et al, 2011).

171 The relationship between the characteristics of the environment and earthworm presence was further

172 analyzed at the genus level, assessing the sensitivity of the groups with the soil parameter values

173 through a Mann-Whitney U-test. The program Statistica 7.0 (Stat Soft, Inc.) was used.

\section{3. Results}

\subsection{Physical and chemical soil parameters}

178 Of all the physical - chemical and microbiological parameters evaluated, only four variables:

179 exchangeable Sodium (Na), Electrical conductivity (EC), Mechanical resistance (MR), and

180 respiration) showed significant statistical differences between each of the three systems and only

181 organic matter (OM) presented no differences (Table 1). From the four variables that separate the three 182 systems, the naturalized grasslands showed the highest $\mathrm{Na}$ levels and EC values.

183 Microbiological activity and soil microfauna were assessed through soil respiration and nitrogen fixing

184 bacteria activity, which separated the naturalized grasslands for their high value when compared to the 
185 other two agroecosystems. Naturalized grasslands were also separated from the other two

186 agroecosystems by having a much higher microbiological and soil microfauna activity.

$187 \quad 3.2$ Earthworm assemblage response to soil use intensity

188 Results show that each soil use presents a different species composition and abundance (Fig 2). The

189 relative abundances of the earthworm species found in each system are shown in figure 3.

190 A total of 9 earthworm species were identified across all systems. Five species were common to all of 191 them: the native Microscolex dubius (Fletcher, 1887) and the exotic Aporrectodea caliginosa (Savigny, 192 1826), A. rosea (Savigny, 1826), Octolasion cyaneum (Savigny, 1826), and O. lacteum (Oerley, 1885), 193 but they differed in their abundances. The differences in abundance explain the significant differences 194 found for the Shannon index values (ANOVA test $\mathrm{p}<0.05$ ). The richness estimate $(\hat{\mathrm{S}})$ and the observed 195 richness $\left(\mathrm{S}_{\text {obs }}\right)$ only differed in the recent agricultural system (Table 2$)$.

196 In the naturalized grasslands, the species identified as being the dominant ( $44 \%$ of all the individuals 197 collected) was the epigeic native M. dubius, followed by the endogeic exotics A. caliginosa, A. rosea, 198 O. cyaneum, and O. lacteum. The other endogeic exotic species, Aporrectodea trapezoides (Dugés, 199 1828), and the native M. phosphoreus (Dugés, 1837), were less frequent (Fig. 3a). Forty seven percent 200 of all the individuals collected belonged to native species, and the ratio natives / exotics was 2:5.

201 In the recent agricultural system, the endogeic native Eukerria stagnalis (Kinberg, 1867) was dominant 202 and the exotic $A$. rosea was also common. Other species that were present, albeit with a low frequency, 203 were A. caliginosa, and M. dubius. M. phosphoreus, O. cyaneum, and O. lacteum appeared on either 204 one or two sampling dates only. In this system, E. stagnalis represents $68 \%$ of all the individuals 205 collected and A. rosea represents $22 \%$ (Fig. 3b). The ratio of native-exotic species was 3:4 .

206 In the intensive agricultural system, the most common species were the endogeic exotics $A$. caliginosa, 207 A. rosea, and A. trapezoides. The other endogeic species $O$. cyaneum, and the epigeic native M. dubius 208 were less frequent. Octolasion tyrtaeum (Savigny, 1826) was only detected in the first sampling date, 209 and $O$. lacteum appeared in two sampling dates with a single individual each date. Here, the exotic 210 species represent $95 \%$ of the individuals (Fig. 3c), with M. dubius being the only native present in this 211 system. The agricultural system had the lowest ratio of native-exotic species (1:6).

212 The differences in the chemical and physical soil parameters and the species requirements determined 213 the species' co-occurrences found in each system. We observed these associations involving both 
214 native and introduced species, and combining different ecological categories. The associations most

215 frequently found in naturalized grasslands were: A. rosea - M. dubius (appearing together in 33\% of

216 the samples), O. cyaneum - O. lacteum (10\%), and A. rosea - O. cyaneum (10\%). In the recent

217 agricultural sites, A. rosea - E. stagnalis were found together in $67 \%$ of the samples, and in the

218 intensive agricultural system, the most common associations were A. caliginosa - A. rosea $(12.5 \%)$,

219 and A. rosea - M. dubius (12.5\%).

220 The relationship between the characteristics of the environment and earthworm presence, assessing the

221 sensitivity of the groups with the soil parameter values is shown in Table 3.

222 Aporrectodea, Octolasion, and Microscolex genus were present in samples with the same levels of $\mathrm{Mg}$,

$223 \mathrm{~K}$, and BD. Octolasion separated from Aporrectodea only because of Ca levels, and its response to soil

224 moisture, MR, and respiration put it close to Microscolex. In turn, Microscolex differed from the other

225 groups due to Na, pH, ARA, and high MR (MR $10 \mathrm{~cm}$ ). On the other hand, Eukerria was related to

226 places with low levels of $\mathrm{Ca}, \mathrm{K}, \mathrm{pH}, \mathrm{EC}, \mathrm{ARA}, \mathrm{BD}, \mathrm{MR}$ and moisture content.

227 In order to know how the species' composition explains the environmental variability, an indirect

228 ordination PCA analysis was used, followed by a vector fitting (Fig. 4). Interestingly, the analysis

229 showed no relationship between species and fertility levels (N, P, and OM), but it did show a

230 relationship with exchangeable $\mathrm{Mg}$ and $\mathrm{Ca}$.

231 The first two axes explain $58 \%$ of the variance. The environmental variables that were significantly

232 related to the species ordination were: moisture, $\mathrm{K}$, ARA, respiration, $\mathrm{MR}, \mathrm{Ca}$, and $\mathrm{pH}$ (adjusted $\mathrm{P}<$ 233 0.05).

234 As shown in Fig. 4, the ordination method shows that M. dubius densities appeared related to the levels 235 of $\mathrm{Ca}, \mathrm{pH}, \mathrm{MR}$ and respiration. This species is well adapted to environments rich in $\mathrm{Ca}$, neutral $\mathrm{pH}$, 236 high microbiological activity, and high mechanical resistance. The environment defined by M. dubius

237 was related to the characteristics of the Naturalized grassland system, and this species can be 238 considered as indicative of the conditions dominant in this system. In the same way, A. caliginosa (Fig.

239 4) is related to high $\mathrm{K}$ levels, low enzymatic activity, low pH, and low Ca. Such soil parameters are 240 characteristic of the Intensive agricultural system, thus making A. caliginosa, a natural cosmopolite 241 and invasive species, a good indicator of high perturbation sites. Finally, E. stagnalis and A. rosea were 242 related to the second ordination factor, and they describe an environment with high soil moisture, low $243 \mathrm{pH}$, low Ca levels, and low ARA. These characteristics describe the Recent agricultural system. 


\section{4. Discussion}

247 These results show that the structure of earthworm assemblages change in relation to differences in soil use intensity in terms of its composition, abundance, and species associations. The data presented here shows that, in the same soil and the same regimen of temperature and precipitation, the earthworm assemblage composition and abundance varied across the different systems studied. These variations describe the physical and chemical differences of soil due to land use intensities and their associated management practices (Geissen et al, 2009).

253 Tillage, weed control, fertilization and soil cover are parameters that best characterize the different land use intensities (Curry, 2004; Viglizzo et al, 2004; Decaëns et al, 2008), modifying the physical (water and air movement) and chemical environment, thus changing the habitat's suitability.

256 In the agricultural system under highest use intensity, earthworm communities were affected directly by the changes caused by tillage practices or indirectly through changes in food supply. Several studies indicate that earthworm communities are more abundant and rich in species in undisturbed soils when compared to cropland (Emmerling 2001; Curry et al, 2008; Decaëns et al, 2008; Feijoo et al, 2011;

260 Felten \& Emmerling, 2011). In this study, however, this pattern was not observed. All three systems

261 have the same richness value but the abundances are consistently higher in the AG system with the 262 highest use intensity. This system also showed the highest native species substitution by exotic ones 263 (ratio 1:1.6). Total individuals belonging to invasive species varied from $16.6 \%$ in the NG system to $26440.4 \%$ in the AG system. These results agree with those of Lee (1985), Paoletti (1999), and Smith et al. 265 (2008), who found that annual croplands have higher earthworm abundance than older fields. The 266 dominance of introduced species is another characteristic of highly disturbed sites, as pointed out by 267 Fragoso et al. (1999), Winsome (2006), and Chan and Barchia (2007).

268 The results presented in this work indicate that the response of the earthworm assemblage to the same 269 soil subjected to different use intensities can be used as an agroecosystem biological indicator. This 270 response can be explained in terms of quality and quantity of food (Bohlen et al, 1997), the long term 271 use of inorganic fertilizers which have a positive effect on the total number of worms (Edwards \& 272 Bohlen, 1996; Curry, 2004), pH changes, and the level of Ca in the soil (Lee, 1985; Paoletti, 1999; 273 Smith et al, 2008). 
274 In the intensive agricultural and recent agricultural systems, microbiological activity was low when

275 compared to the naturalized grasslands. This can be explained as the result of a reduction in $\mathrm{pH}$ and $\mathrm{Ca}$,

276 as well as by the ecological categories of the earthworm species present (Scheu et al, 2002). Indeed,

277 Scheu (2003) indicated that the presence of endogean species significantly reduces bacterial biomass

278 and the functioning of the microbial assemblage. In the AG system, $95 \%$ of the species present are

279 exotic endogeans, while in the RA system $97 \%$ are endogean ( $70 \%$ native, $30 \%$ exotic).

280 Soil use intensity was also indicated by the presence of a few species that were closely related to

281 environmental variability. The intensification of the agricultural activities in the Pampas determined up

282 to a $50 \%$ reduction in the calcium level (Casas, 2005). The ordination analysis related M. dubius with

283 high Ca levels and thus, to less disturbed environments.

284 In fact, Mele and Carter (1999) point out that the distribution and number of native species are 285 negatively correlated with $\mathrm{P}, \mathrm{K}$, and $\mathrm{Mg}$ levels, since these species are adapted to lower nutrient levels.

286 In our study, the only species that is related to higher $\mathrm{K}$ levels is $A$. caliginosa, which is the most 287 abundant earthworm in the intensive agricultural system.

\section{Conclusions}

291 The data from this study indicate that the three agricultural systems are different in terms of the levels

292 of exchangeable cations ( $\mathrm{Ca}, \mathrm{K}), \mathrm{pH}$, microbiological activity, and physical variables such as

293 mechanical resistance and moisture. While the Argiudoll soil type is the same for all three systems,

294 changes in land use intensity caused the observed differences in the soil's chemical and physical

295 properties. Earthworm species assemblages also reflected the changes in these variables and are

296 therefore good indicators of the systems studied.

297 The high diversity and highest number of earthworms found in the agricultural system under no tillage

298 are consistent with the results by Pelosi, Bertrand \& Roger-Estrade (2009), who found that soil tillage

299 and surface mulch are important parameters for the study of the effects of agricultural practices on

300 earthworm communities.

301 Microscolex dubius was associated with sites exhibiting high levels of $\mathrm{Ca}$, microbiological activity, and

302 high mechanical resistance; thus describing the naturalized grassland system. Eukerria stagnalis is

303 primarily associated with high moisture condition, and A. caliginosa is associated with highly disturbed 
304 environments, those with high $\mathrm{K}$ levels, low $\mathrm{EC}$ and $\mathrm{Na}$, and low microbiological activity, all typical of 305 the intensive agricultural system.

306 Eukerria stagnalis is indicative of high moisture condition, increased soil acidity, and a reduction in

307 the levels of calcium and potassium, which are conditions prevalent in the intermediate use intensity 308 system.

309 Aporrectodea caliginosa is the species best adapted to the most disturbed environment. This implies

310 that the population recovers quickly after a disturbance (Curry, 2004, Felten \& Emmerling, 2011;

311 Decaëns, 2011), as it is known not to be significantly affected by changes in litter quality (Curry \&

312 Schmidt, 2007).

313 It is interesting to note that the earthworm species most related to the different systems are not linked

314 to the variables most usually measured: OM, N, and P. Therefore, monitoring these species would

315 provide indirect indication of nutrient variables, such as $\mathrm{Mg}$, Ca or K (Fig. 4), thus complementing the

316 information provided by other more common soil analyses in agro-ecosystems.

317 The patterns in the distribution and abundance of earthworm species observed in this study followed

318 the differences in the physical and chemical variables measured in the different systems. An important

319 difference between the studied systems is related to the agrochemicals used in the AG system.

320 Earthworms are strongly affected by herbicide and insecticide use (Pelosi et al, 2014, Santadino,

321 Coviella, \& Momo, 2014), and was likely also reflected in the differences in earthworm composition

322 observed in the present study. All of these differences are, in turn, a reflection of the different

323 management practices applied to the same Argiudol.

324 The richness, composition and abundance, as well as the species associations found, reflected the

325 physical, chemical, and biological changes brought about as a result of the different intensities of the

326 agricultural practices used in each system. The high abundance of the native M. dubius was associated

327 with less anthropic activity. As a result, a strong population density reduction of this species can be

328 interpreted as indicative of a high disturbance regime. On the other hand, A. caliginosa increased its

329 density as disturbance increased. The presence of A. caliginosa, is clearly associated with highly

330 disturbed environments as it was indeed found in several other published works (Johnston, et al, 2014;

331 Lüscher et al, 2014). 
332 An increase in soil use intensity leads to changes in the physical and chemical properties of the same

333 original soil. Earthworm assemblages are then affected by two main mechanisms. Firstly, by the

334 agrochemical and mechanical perturbations introduced by intensive agricultural practices. Secondly, by

335 the effects that the changes in the chemical variables have on earthworm assemblages (e.g. Ca content).

336 On the other hand, as ecosystem engineers, earthworms affect edaphic variables, for example,

337 microbiological activity. Therefore, the association between presence and abundance of the different

338 earthworm species can be used as a biological indicator of the physical and chemical conditions of the

339 soil they inhabit.

340 These results show that the structure of the earthworm assemblages can be reliably used for monitoring

341 different soil use intensities.

\section{Acknowledgements}

343 The authors wish to acknowledge the collaboration of Edgardo Ferrari, Pablo Peretto, and Romina de

344 Luca for allowing the use of their fields as sampling sites. Ms. Loreta Gimenez greatly helped with

345 field and laboratory works. The help of Dr. John T. Eigenbrode and Dr. Beth Frankel with previous

346 English versions, and that of Dr. Mark Breidenbaugh with the final revision of the English version of

347 this manuscript are greatly appreciated. The revision of previous drafts by Dr. Adonis Giorgi is also

348 appreciated. 
Bohlen, P.J., Parmelee, R.W., McCartney, D.A., Edwards, C.A., 1997.Earthworm effects on carbon and nitrogen dynamics of surface litter in corn agroecosystems. Ecological Applications 7:1341-1349.

Cabrera, A., Willink, A., 1973. Biogeografía de América Latina. Serie de Biología. Monografía No. 13. Programa Regional de Desarrollo Científico y Tecnológico. Departamento de Asuntos Científicos. Secretaría General de la Organización de los Estados Americanos, Washington.

Casas, R.R., 2005. Efecto de la intensificación agrícola sobre los suelos. Ciencia Hoy. Vol. XV. 87: 42 -43.

Chan, K.Y., Barchia, I., 2007. Soil compaction controls the abundance, biomass and distribution of earthworms in a single dairy farm in south-eastern Australia. Soil \& Tillage Research. 94: 7582

Coleman, D.C., Crossley, D.A., 1996. Fundamentals of soil ecology. Academic Press, San Diego, CA. $205 \mathrm{pp}$.

Curry, J.P., Schmidt, O., 2007. The feeding ecology of earthworms - A review. Pedobiologia (Jena). $50,463-477$.

Curry, J.P., 2004. Factors affecting the abundance of earthworms in soils. In: Edwards, C.A. (Ed.), Earthworm Ecology. CRC press LLC, Boca Raton, FL, pp. 91-114.

Curry, J.P., Byrne, D., Schmidt, O., 2002. Intensive cultivation can drastically reduce earthworm populations in arable land. European Journal of Soil Biology. 38, 127-130.

Curry, J.P., Doherty, P., Purvis, G., Schmidt, O., 2008. Relationships between earthworm populations and management intensity in cattle-grazed pastures in Ireland. Applied Soil Ecology, 39, 5864.

Dale, V.H., Polasky, S., 2007. Measures of the effects of agricultural practices on ecosystem services. Ecological Economics. 64, 286-296.

Decaëns, T., Margerie, P., Renault, J., Bureau, F., Aubert, M., Hedde, M., 2011. Niche overlap and species assemblage dynamics in an ageing pasture gradient in north-western France. Acta Oecologica. 37,212-219.

Decaëns, T., Margerie, P., Aubert, M., Hedde, M., Bureau, F., 2008. Assembly rules within earthworm communities in North-Western France: regional analysis. Applied Soil Ecology 39,321-335.

Dennis, P., Bogers, M.M.B., Bunce, R.G.H., Herzog, F., Jeanneret, P., (Eds.) (2012) Biodiversity in organic and low-input farming systems. Handbook for recording key indicators. Alterra Report 2308. Wageningen University. Alterra ISSN 1566-7197

Edwards, C.A., Bohlen, P.J., 1996. Biology and ecology of earthworms. 426 pp. Chapman \& Hall, London.

Emmerling C, (2001) Response of earthworm communities to different types of soil tillage. Applied Soil Ecology.17, 91-96.

Falco, L., Momo, F.,1995. Asociaciones de lombrices de tierra y su relación con la cobertura vegetal en suelos forestados. Revista Chilena Historia Naturales. 68:523 -28. ISSN/ISBN: 0716078X.

Falco, L., Momo, F., 2010.Selección de Hábitat: efecto de la cobertura y tipo de suelo en lombrices de tierra. Acta Zool. Mex. Nro. Especial 2.179-187. ISSN 0065-1737.

Feijoo, A., Carvajal, A.F., Zúñiga, M.C., Quintero,H., Fragoso,C., 2011. Diversity and abundance of Earthworms in land use systems in central-western Colombia. Pedobiologia 54S: S69-S75. 
Felten, D., Emmerling, C., 2011. Effects of bioenergy crop cultivation on earthworm communities - A comparative study of perennial (Miscanthus) and annual crops with consideration of graded land -use intensity. Applied Soil Ecology. 49, 167-177.

Fragoso, C., Lavelle, P., Blanchart, E., Senapati, B., Jimenez, J., Martínez, M de los A., Decaëns, T., Tondoh, J.,1999. Earthworm communities of tropical agroecosystems: origin, structure and influences of management practices. In: Lavelle, P., Brussaard, L., Hendrix, P.(Eds.). Earthworm Management in Tropical Agroecosystems. CAB International, Wallingford, UK, pp. 27-55.

Geissen, V., Peña-Peña, K., Huerta, E., 2009. Effects of different land use on soil chemical properties, decomposition rate and earthworm communities in tropical Mexico. Pedobiologia 53:75-86. DOI 10.1016/j.pedobi.2009.03.004.

Hommel, G., 1988. A stagewise rejective multiple test procedure based on a modified Bonferroni test. Biometrika. 75:383-386.

Johnson-Maynard, J.L., Umiker, K.J., Guy, S.O., 2007. Earthworm dynamics and soil physical properties in the first three years of no-till management. Soil \& Till. Res. 94, 338-345.

Johnston, A.S.A., Hodson, M.E., Thorbek, P., Alvarez, T., Sibly, R.M.,2014. An energy budget agentbased model of earthworm populations and its application to study the effect of pesticides. Ecol. Model. http://dx.doi.org/10.1016/j.ecolmodel.2013.09.012.

Jouquet, P., Bottinelli, N., Podwojewski ,P., Hallaire ,V., Duc, T.T., 2008. Chemical and physical properties of earthworm casts as compared to bulk soil under a range of different land-use systems in Vietnam. Geoderma. 146, 231-238.

Lavelle, P., Spain, A.V., 2001. Soil ecology . Kluwer Academic Publishers, London. UK. 620 pp

Lavelle, P., Bignell, D., Lepage, M., Wolters, V., Roger, P., Ineson, P., Heal, O.W., Dhilloin, S., 1997. Soil function in a changing world: the role of invertebrate ecosystem engineers. Eur. J. Soil Biol. 33, 159-193.

Lavelle, P., Decaëns, T., Aubert, M., Barot, S., Blouin, M., Bureau, F., Margerie, P., Mora, P., Rossi, J.P., 2006. Soil invertebrates and ecosystem services. Eur. J. Soil Biol. 42, S 3-S15.

Lee, K.E., 1985. Earthworms: Their Ecology and Relationships with Soils and Land use. Academic Press, New York, 411 pp.

Legendre, P., Gallagher, E., 2001. Ecologically meaningful transformations for ordination of species data. Oecologia. 129: 271-280.

Lüscher, G., Jeanneret, P., Schneider, M.K., Turnbull, L.A., Arndorfer, M., Balázs, K., Báldi, A., Bailey, D.,. Bernhardt, K.G., Choisis, J.P., Elek, Z., Frank, T., Friedel, J.K., Kainz, M., Kovács-Hostyánszki, A., Oschatz, M.L.,. Paoletti, M.G., Papaja-Hülsbergen, S., Sarthou, J.P., Siebrecht, N., Wolfrum, S., Herzog, F., 2014. Responses of plants, earthworms, spiders and bees to geographiclocation, agricultural management and surrounding landscape in European arable fields. Agric. Ecosyst. And Environ. 186: 124-134.

Magurran, A.E., 2004. Measuring biological diversity. Oxford University Press, Oxford. 256 pp.

Mather, J.G., Christensen, B.T., 1988. Surface movements of earthworms in agricultural land. Pedobiologia (Jena). 32: 399-405.

Mele, P.M., Carter, M.R., 1999. Species abundance of earthworms in arable and pasture soils in southeastern Australia. Appl. Soil Ecol. 12,129-137.

Momo, F., Falco, L., Craig, E., 2003. Las Lombrices de Tierra como Indicadoras del Deterioro del Suelo. Revista de Ciencia y Tecnología Serie Científica N8:55-63. ISSN/ISBN: 03285936.

Navarrete, M., Gallopín, D., Blanco, G., Díaz-Zorita, M., Ferraro, M., Herzer, D., Laterra, H., Murmis, P., Podestá, G., Rabinovich, J., Satorre, E., Torres, F., Viglizzo, E., 2009. Multi-causal and 
integrated assessment of sustainability: the case of agriculturization in the argentine pampas. Environment, Development and Sustainability. 11(3):621-638.

Oksanen, F.J., Blanchet, G., Kindt, R., Legendre, P., Minchin, P.R., O'Hara, R.B., Simpson, G.L., Solymos, P., Stevens, M.H.H., Wagner, H., 2011. Vegan: Community Ecology Package. R package version 2.0-1. Stable URL: http://CRAN.R-project.org/package=vegan. Accessed: 22/11/2012.

Paoletti, M.G., 1998. Earthworms as useful bioindicators of agroecosystem sustainability in orchards and vineyards with different inputs. Appl. Soil. Ecol. 10,137-150.

Paoletti, M.G., 1999. The role of earthworms for assessment of sustainability and as bioindicators. Agric Ecosyst Environ. 74,137-155.

Pelosi, C., Bertrand, M., Roger-Estrade. 2009.Earthworm community in conventional, organic and direct seeding with living mulch cropping systems. Agronomy for Sustainable Development, 29 (2):287-295. <hal-00886495>

Pelosi, C., Bertrand, M., Thénard, J., Mougin, C., 2015. Earthworms in a 15 year agricultural trial. Appl. Soil Ecol. 88, 1-8.

Pelosi, C., Barot, S., Capowiez, Y., Hedde, M., Vandenbulcke, F., 2014. Pesticides and earthworms. A review. Agron. Sustain. Dev. 34:199-228.

Power, A.G., 2010. Ecosystem services and agriculture: tradeoffs and synergies. (Review) Philos Trans R Soc Lond B Biol Sci.365, 2959-2971.

R Core Team, 2012. R: A language and environment for statistical computing. R Foundation for Statistical Computing, Vienna, Austria. ISBN 3-900051-07-0, http://www.R-project.org/.

Reynolds, J., 1996. Earthworms biology and Ecology. ISBN 0-9690911-4-1.

Righi, G., 1979. Introducción al estudio de las Lombrices del Suelo (Oligoquetos Megadrilos) de la Provincia de Santa Fe (Argentina). Revista Asociación Ciencias Naturales del Litoral, 10: 89155.

Santadino, M.V., Coviella, C.E., Momo, F.R., 2014. Glyphosate sublethal effects on the Population Dynamics of the Earthworm Eisenia fetida (Savigny, 1826). Water Air Soil Pollut. 225:2207. DOI 10.1007/s11270-014-2207-3.

Satchell, J.E., 1967. Lumbricidae. Pp. 259-322. In: A. Burges and F. Raw (Eds.) Soil Biology. Academic Press, London.

Scheu, S., Albers, D., Alphei, J., Buring, R., Klages, U., Migge, S., Platner, C., Salomon, J.A., 2003. The soil fauna community in pure and mixed stands of beech and spruce of different age: trophic structure and structuring forces. Oikos. 101:225-238.

Scheu, S., Schlitt, N., Tiunov, A., Newington, J., Jones, H.T., 2002. Effects of the presence and community composition of earthworms on microbial community functioning. Oecologia. 133, 254-260.

Six, J., Bossuyt, H., Degryze, S., Denef, K., 2004. A history of research on the link between (micro) aggregates, soil biota and soil organic matter dynamics. Soil \& Till. Res. 79, 7-31.

Smith, R., McSwiney, C., Grandy, A., Suwanwaree, P., Snider, R., Robertson, G., 2008. Diversity and abundance of earthworms across an agricultural land-use intensity gradient. Soil \& Tillage Research. 100, 83-88.

United States Department of Agriculture, 2010. Keys to Soil Taxonomy Eleventh Edition. 338 pp.

Viglizzo, E.F., Pordomingo, A.J., Castro, M.G., Lértora, F.A., 2003. Environmental assessment of agriculture at a regional scale in the Pampas of Argentina. Environ Monit Assess. 87 (2), $169-195$. 
485 Viglizzo, E.F., Pordomingo, A.J., Castro, M.G., Lértora, F.A., Bernardos, J.N., 2004. Scale-dependent 486 controls on ecological functions in agroecosystems of Argentina. Agric Ecosyst Environ.101, $39-51$.

Winsome, T., Epstein, L., Hendrix, P.F., Horwath, W.R., 2006.Competitive interactions between native and exotic earthworm species as influenced by habitat quality in a California grassland. Agric.,

491 Zar, J.H., 1999. Biostatistical Analysis $4^{\text {th }}$ Edition. Prentice Hall. New Jersey. 662 p. 
1

Sampling sites

Figure 1: Map showing the location of the sampling sites

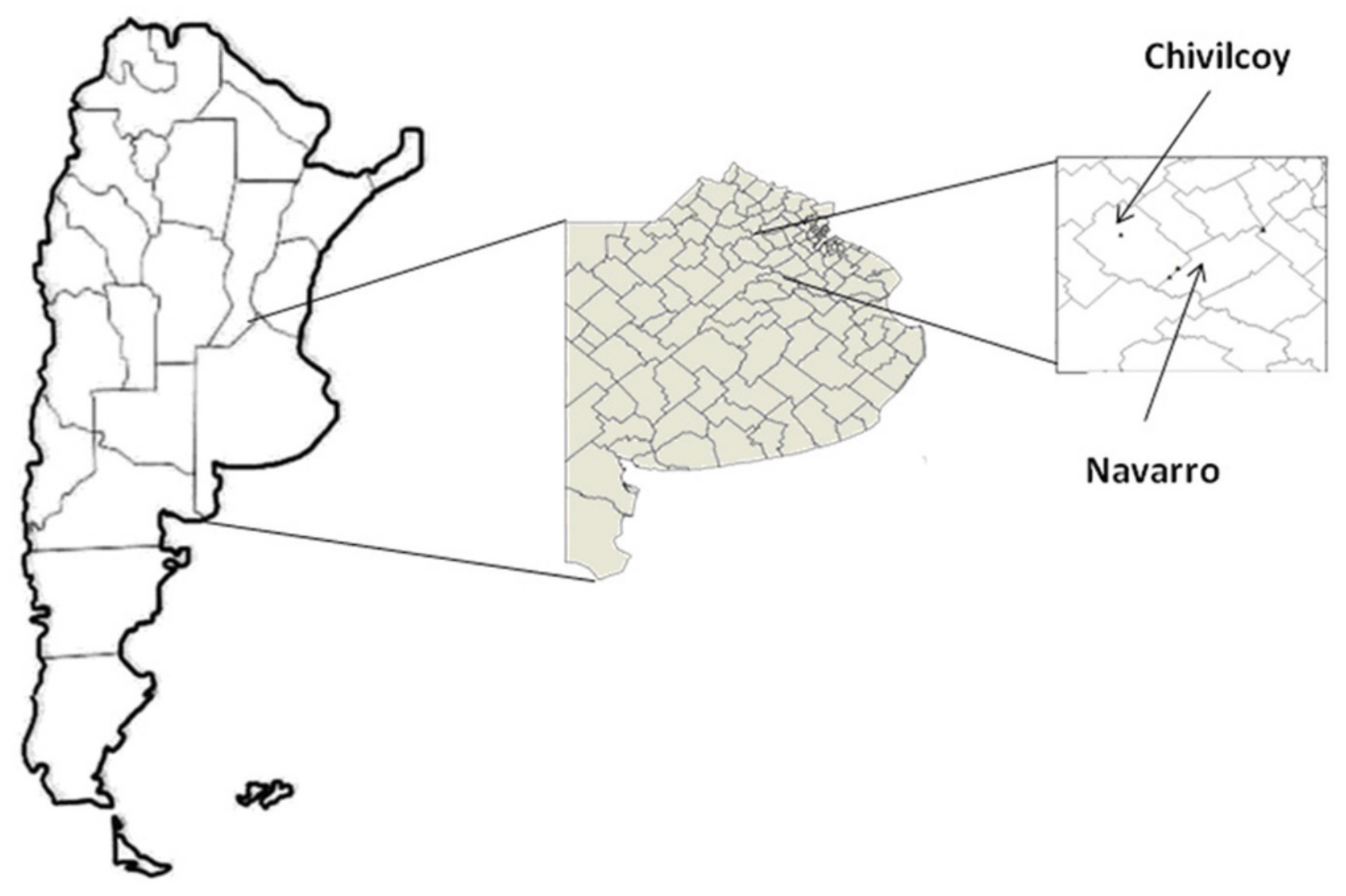




\section{2}

Earthworm species per system

Figure 2: Abundance $(\mathrm{N})$ of each earthworm species throughout the total sampling period for each system. NG: Naturalized grasslands; RA: Recent agriculture; AG Intensive agriculture

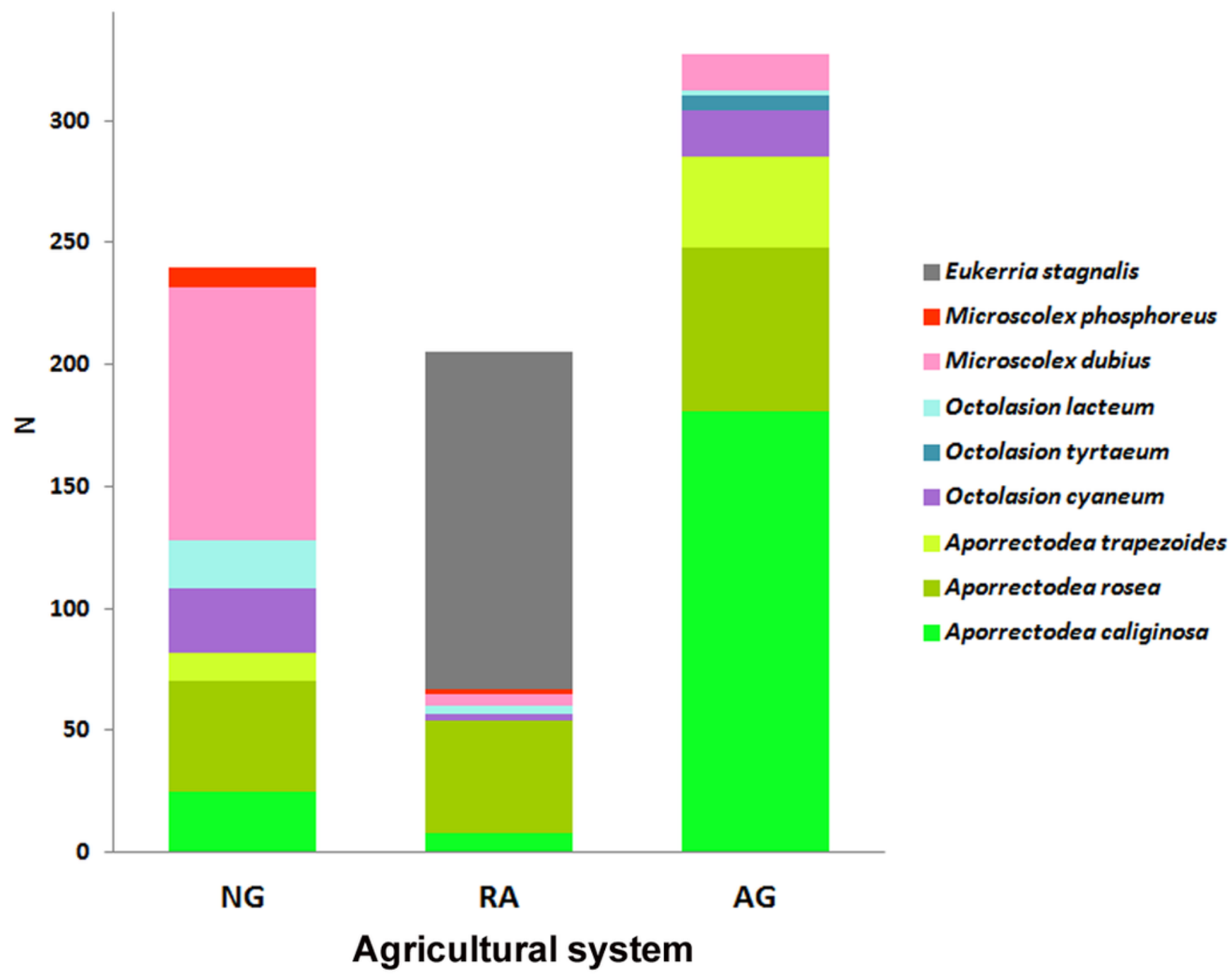


3

Rank-abundance plot

Figure 3: Relative abundance (ni/N) for each earthworm species identified in the three systems. A: Naturalized grassland (NG), B: Recent agricultural (RA), C: Agricultural system (AG). Ac : A. caliginosa, Ar: A. rosea; At: A. trapezoides; Ot: O. tyrtaeum; Md: M. dubius; Oc: O. cyaneum; OI: O. lactuem; Es: E. stagnalis; Mp: M. phosphoreus. Native species shown in green, exotics in black. 


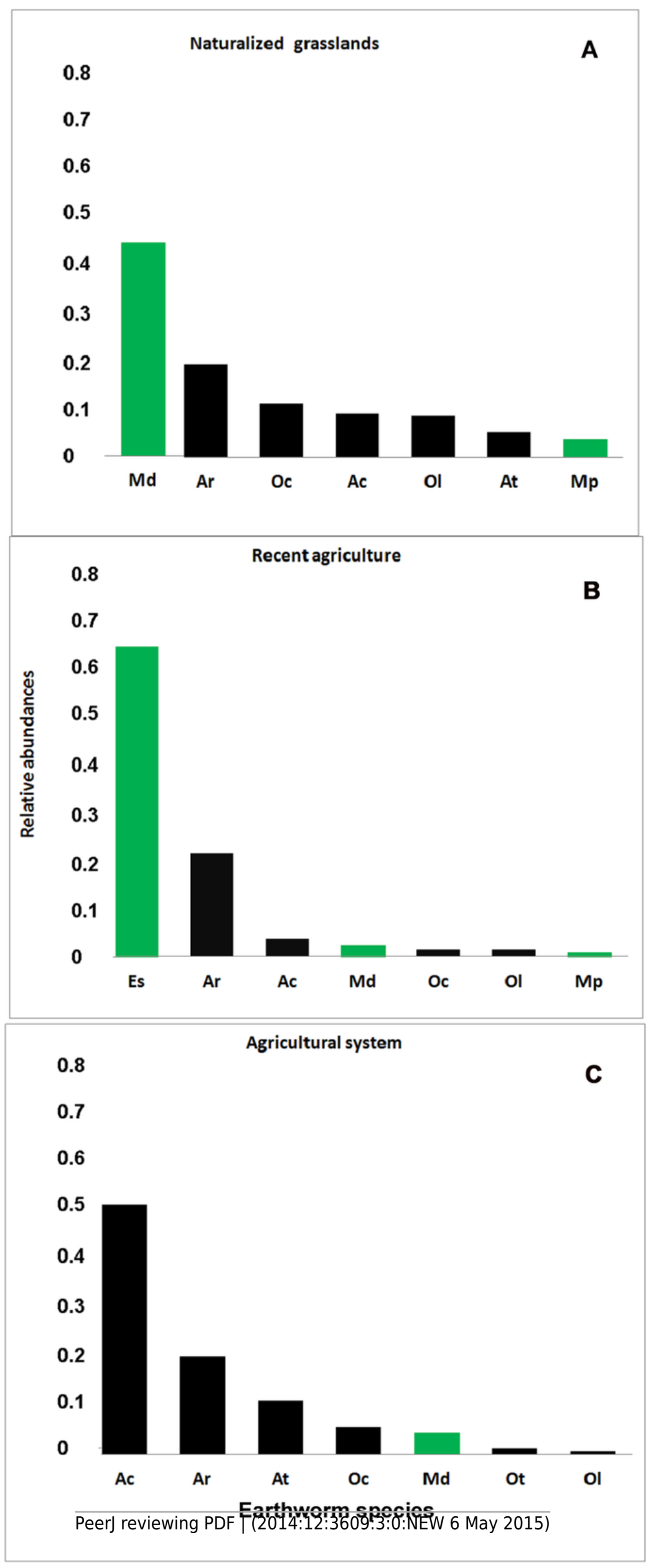


4

Principal Component Analysis

Figure 4: PCA biplot of Hellinger transformed earthworm species, only the four most abundant ones are shown. The arrows are significant environmental variables fitted into the ordination space. The percentage of explained variance is shown in each axis. Ac: $A$. caliginosa; Ar: A. rosea; Es: E. stagnalis; Md: M. dubius. 


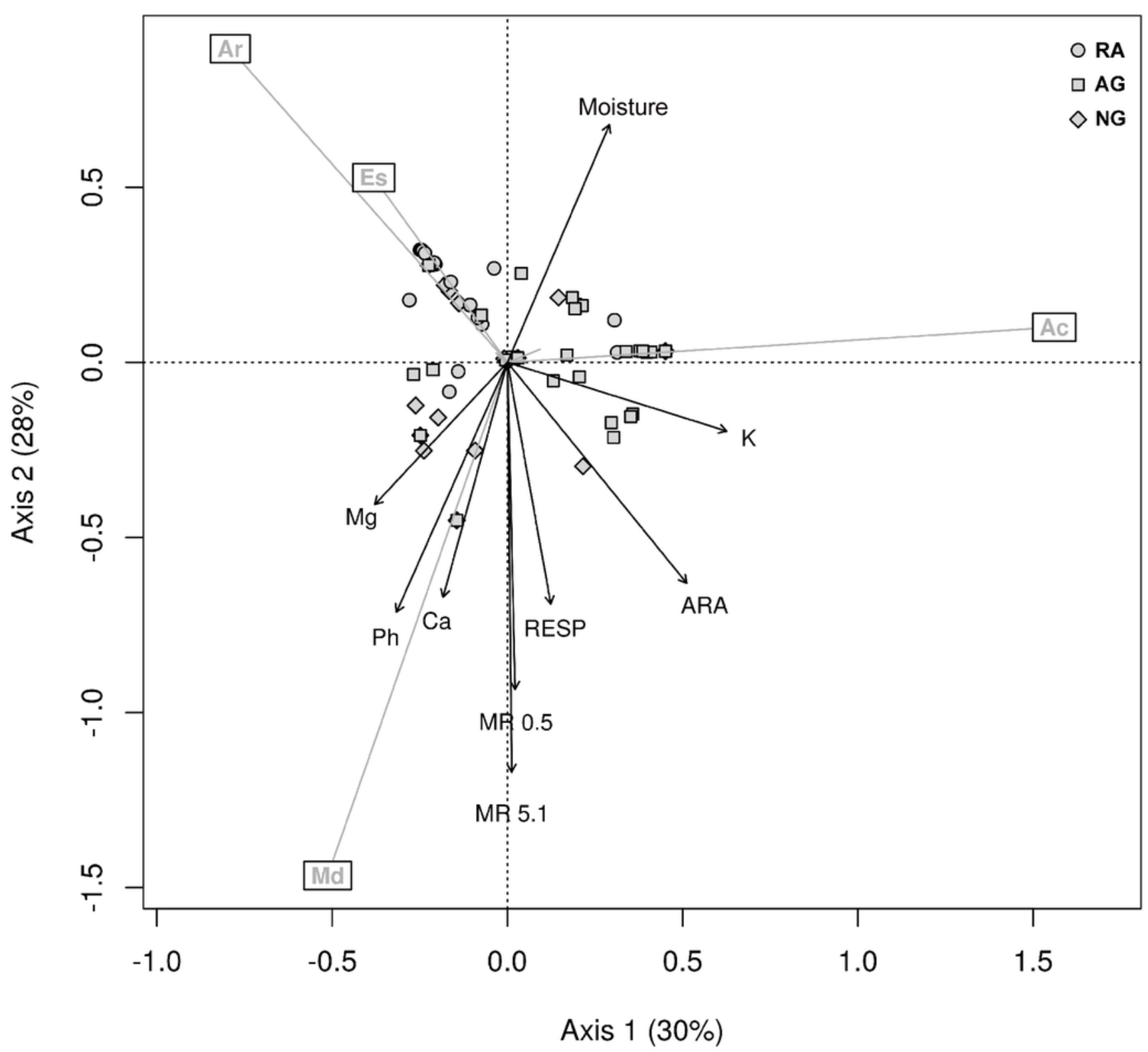


Table 1 (on next page)

Physicochemical and microbiological parameters measured

Table 1: Physicochemical and microbiological parameters measured ( $n=150$ per system). NG: Naturalized grassland; RA: Recent agriculture, AG; Intensive agricultural system. Different letters within a row indicate significant differences between systems, $\mathrm{P}<0.05$ Kruskall-Wallis ANOVA tests. Means \pm SE shown. P: Phosphorus; OM: Organic Matter; EC: Electrical conductivity; Ca: Calcium; Mg: Magnesium; Na: Sodium; K: Potassium; MR: Mechanical resistance; ARA: Acetylene Reduction Activity. 


\begin{tabular}{|c|c|c|c|c|c|c|}
\hline \multirow{2}{*}{ Parameters } & \multirow{2}{*}{ Method } & \multicolumn{5}{|c|}{ System } \\
\hline & & NG & & RA & & $\mathrm{AG}$ \\
\hline Available P (ppm) & Kurtz and Bray & $11 \pm 8.5$ & $\mathrm{~b}$ & $15 \pm 12$ & $\mathrm{a}$ & $14 \pm 12$ \\
\hline $\mathrm{OM}(\%)$ & Walkey-Black & $4 \pm 1.5$ & $\mathrm{a}$ & $4 \pm 1.5$ & $\mathrm{a}$ & $4 \pm 1.4$ \\
\hline $\mathrm{EC}\left(\mathrm{dS} * \mathrm{~m}^{-1}\right)$ & conductivimeter & $1,5 \pm 1.3$ & $\mathrm{a}$ & $0.8 \pm 0.5$ & $\mathrm{~b}$ & $0.7 \pm 0.5 \mathrm{c}$ \\
\hline $\mathrm{pH}$ & $\begin{array}{l}1: 2 \text { soil to water } \\
\text { ratio }\end{array}$ & $7.5 \pm 1.0$ & $\mathrm{a}$ & $6 \pm 0.6$ & $\mathrm{~b}$ & $6 \pm 0.5$ \\
\hline Bulk density $\left(\mathrm{g}^{*} \mathrm{~cm}^{-3}\right)$ & Cylinder method & $1.2 \pm 0.2$ & $\mathrm{a}$ & $1.1 \pm 0,1$ & $\mathrm{~b}$ & $1.2 \pm 0.1 \quad \mathrm{a}$ \\
\hline $\begin{array}{l}\text { Moisture content ( } \mathrm{g} \text { water* } \mathrm{g} \\
\text { soil }^{-1} \text { ) }\end{array}$ & gravimetric & $0.2 \pm 0.1$ & $\mathrm{a}$ & $0.3 \pm 0.1$ & $\mathrm{~b}$ & $0.2 \pm 0.1 \quad \mathrm{a}$ \\
\hline Exch. $\mathrm{Ca}\left(\mathrm{cmol}^{*} \mathrm{~kg}\right.$ soil $\left.^{-1}\right)$ & $\begin{array}{l}\text { titration with } \\
\text { EDTA }\end{array}$ & $6.7 \pm 1.3$ & $\mathrm{a}$ & $5 \pm 0.5$ & $\mathrm{~b}$ & $6 \pm 0.7$ \\
\hline Exch. $\mathrm{Mg}\left(\mathrm{cmol}^{*} \mathrm{~kg}\right.$ soil $\left.^{-1}\right)$ & $\begin{array}{l}\text { titration with } \\
\text { EDTA }\end{array}$ & $1.8 \pm 0.4$ & $\mathrm{a}$ & $1.5 \pm 0.7$ & $\mathrm{~b}$ & $1.6 \pm 0.5 \mathrm{~b}$ \\
\hline Exch. Na $\left(\mathrm{cmol}^{*} \mathrm{~kg}\right.$ soil $\left.^{-1}\right)$ & flame photometry & $1.3 \pm 0.5$ & $\mathrm{a}$ & $0.8 \pm 0.2$ & $\mathrm{~b}$ & $0.7 \pm 0.2 \mathrm{c}$ \\
\hline Exch. K $\left(\mathrm{cmol}^{*} \mathrm{~kg}\right.$ soil $\left.^{-1}\right)$ & flame photometry & $1.6 \pm 0.5$ & $\mathrm{a}$ & $1.3 \pm 0.3$ & $\mathrm{~b}$ & $1.6 \pm 0.5 \mathrm{a}$ \\
\hline Total N (\%) & Kjeldahl & $0.28 \pm 0.1$ & $\mathrm{a}$ & $0.32 \pm 0.1$ & $\mathrm{~b}$ & $0.29 \pm 0.05 b$ \\
\hline $\begin{array}{l}\text { Nitrogenase activity (nanolitres } \\
\text { of ethylene* } \mathrm{g} \text { dry } \\
\text { soil*incubation hour }^{-1} \text { ) }\end{array}$ & ARA & $0.3 \pm 0.3$ & $\mathrm{a}$ & $0.2 \pm 0.2$ & $\mathrm{~b}$ & $0.2 \pm 0.3$ \\
\hline $\begin{array}{l}\text { Respiration }\left(\mathrm{mg} \mathrm{CO}_{2} * \mathrm{~g} \text { dry soil }\right. \\
\left.\text { day }^{-1}\right)\end{array}$ & $\begin{array}{l}\text { alkaline } \\
\text { incubation }\end{array}$ & $0.09 \pm 0.06$ & 5 a & $0.07 \pm 0.05$ & $b$ & $0.05 \pm 0.05 \mathrm{c}$ \\
\hline MR 0-5 $\mathrm{cm}\left(\mathrm{kg}^{*} \mathrm{~cm}^{-2}\right)$ & $\begin{array}{l}\text { Cone } \\
\text { penetrometer }\end{array}$ & $10 \pm 6$ & $\mathrm{a}$ & $2.5 \pm 3$ & $\mathrm{~b}$ & $5.5 \pm 4$ \\
\hline MR 5-10 $\mathrm{cm}\left(\mathrm{kg}^{*} \mathrm{~cm}^{-2}\right)$ & $\begin{array}{l}\text { Cone } \\
\text { penetrometer }\end{array}$ & $13 \pm 7$ & $\mathrm{a}$ & $5 \pm 5$ & $\mathrm{~b}$ & $8 \pm 5$ \\
\hline
\end{tabular}




\section{Table 2 (on next page)}

Ecological parameters measured

Table 2: Observed and estimated species richness, mean density, and Shannon diversity index. $\mathrm{S}_{\text {obs }}=$ Observed richness. Different letters in the Shannon index column indicate significant differences (one-way ANOVA $p<0.05$ ) 


\begin{tabular}{|c|c|c|c|cc|}
\hline & $\begin{array}{c}\text { Richness } \\
\text { observed } \\
\left(\mathrm{S}_{\mathrm{obs}}\right)\end{array}$ & $\begin{array}{c}\text { Richness } \\
\text { estimate } \\
(\mathrm{Chao})\end{array}$ & $\begin{array}{c}\text { Density } \\
(\text { individuals/ } \\
\left.\mathrm{m}^{2}\right)\end{array}$ & $\begin{array}{c}\text { Shannon } \\
\text { index }\end{array}$ \\
\hline Naturalized grassland & 7 & $7 \pm 0$ & $46 \pm 19$ & 0.53 & $\mathrm{a}$ \\
\hline Recent agriculture & 7 & $8.5 \pm 1,5$ & $40 \pm 55$ & 0.37 & $\mathrm{~b}$ \\
\hline $\begin{array}{c}\text { Intensive agricultural } \\
\text { system }\end{array}$ & 7 & $7.25 \pm 0,4$ & $76 \pm 56$ & $0.57 \quad \mathrm{a}$ \\
\hline
\end{tabular}

3

4

5 
Table 3 (on next page)

Variables measured at the sampling points where each earthworm genus was recorded

Table 3: Mean (range) values of each measured variable as they relate to earthworm genus presence (Non-clitelated specimens included). Different letters within each row indicate significant differences between earthworm genus, $\mathrm{P}<, 0.05$ Mann-Whitney U-test pairwise comparisons. Abbreviations as in Table 1. 


\begin{tabular}{|c|c|c|c|c|}
\hline Parameter & Aporrectodea & Octolasion & Microscolex & Eukerria \\
\hline OM (\%) & $\begin{array}{c}4.4 \\
(3.7-5.3) \mathrm{a}\end{array}$ & $\begin{array}{c}4.8 \\
(4.4-6.1) \mathrm{a}\end{array}$ & $\begin{array}{c}4.9 \\
(3.2-5.9) \mathrm{a}\end{array}$ & $\begin{array}{c}4.7 \\
(4-5.9) \mathrm{a}\end{array}$ \\
\hline $\mathrm{N}(\%)$ & $\begin{array}{c}0.29 \\
(0.26-0.33) \mathrm{a}\end{array}$ & $\begin{array}{c}0.29 \\
(0.26-.33) \mathrm{a}\end{array}$ & $\begin{array}{c}0.29 \\
(0.27-0.34) \\
\mathrm{a}\end{array}$ & $\begin{array}{c}0.29 \\
(0.25-0.34) \\
\mathrm{a}\end{array}$ \\
\hline Available P (ppm) & $\begin{array}{c}8.7 \\
(4.4-17.6) \mathrm{a}\end{array}$ & $\begin{array}{c}7.7 \\
(3.6-15.2) \mathrm{a}\end{array}$ & $\begin{array}{c}9.3 \\
(4.8-15) \mathrm{a}\end{array}$ & $\begin{array}{c}6.8 \\
(4.4-14.1) \\
\mathrm{a}\end{array}$ \\
\hline Exch. Ca $\left(\mathrm{cmol}^{*} \mathrm{~kg}\right.$ soil $\left.^{-1}\right)$ & $\begin{array}{c}6.0 \\
(5.5-6.4) \mathrm{a}\end{array}$ & $\begin{array}{cc}6.6 & \\
(6.1-9) & b\end{array}$ & $\begin{array}{c}6.1 \\
(5.8-7) \quad \mathrm{c}\end{array}$ & $\begin{array}{c}5 \\
(4.6-5.4) \mathrm{d}\end{array}$ \\
\hline Exch. $\mathrm{Mg}\left(\mathrm{cmol}^{*} \mathrm{~kg}\right.$ soil $\left.^{-1}\right)$ & $\begin{array}{l}1.7 \\
(1.1-2 \mathrm{a}\end{array}$ & $\begin{array}{c}1.7 \\
(1.1-1.9) \mathrm{a}\end{array}$ & $\begin{array}{c}1.6 \\
(1.5-1.9) \mathrm{a} \\
\end{array}$ & $\begin{array}{c}1.1 \\
(1-1.6) b\end{array}$ \\
\hline Exch. $\mathrm{Na}\left(\mathrm{cmol}^{*} \mathrm{~kg}\right.$ soil $\left.^{-1}\right)$ & $\begin{array}{rr}0.8 & \\
(0.7-1) \quad \mathrm{a}\end{array}$ & $\begin{array}{c}0.74 \\
(0.4-0.9) \mathrm{a} \\
\end{array}$ & $\begin{array}{c}0.9 \\
(0.7-1.1) \mathrm{b}\end{array}$ & $\begin{array}{c}0.8 \\
(0.7-1.1) \mathrm{a}\end{array}$ \\
\hline Exch. K (cmol*kg soil $\left.{ }^{-1}\right)$ & $\begin{array}{c}1.3 \\
(1.1-1.7) \mathrm{a}\end{array}$ & $\begin{array}{c}1.5 \\
(1.2-1.8) \mathrm{a}\end{array}$ & $\begin{array}{c}1.3 \\
(1.1-1.8) \mathrm{a}\end{array}$ & $\begin{array}{r}1.1 \\
(1-1.4) \quad b\end{array}$ \\
\hline $\mathrm{pH}$ & $\begin{array}{c}6.2 \\
(5.8-7) \quad \text { a }\end{array}$ & $\begin{array}{r}6.3 \\
(6-6.8) \quad \mathrm{a}\end{array}$ & $\begin{array}{c}6.8 \\
(6.2-7.2) \mathrm{b}\end{array}$ & $\begin{array}{c}6 \\
(5.6-6.5) \mathrm{c}\end{array}$ \\
\hline $\mathrm{EC}\left(\mathrm{dS}^{*} \mathrm{~m}^{-1}\right)$ & $\begin{array}{c}0.6 \\
(0.3-0.9) \mathrm{a}\end{array}$ & $\begin{array}{c}0.6 \\
(0.3-0.9) \mathrm{a}\end{array}$ & $\begin{array}{c}0.7 \\
(0.3-1.2) \mathrm{a}\end{array}$ & $\begin{array}{c}0.4 \\
(0.2-0.7) \mathrm{b}\end{array}$ \\
\hline $\begin{array}{l}\text { Nitrogenase activity } \\
\left(\text { nanolitres of ethylene }{ }^{*} \mathrm{~g}\right. \\
\text { dry soil }^{*} \text { incubation hour }{ }^{-1} \text { ) }\end{array}$ & $\begin{array}{c}0.15 \\
(0.07-0.3) \mathrm{a}\end{array}$ & $\begin{array}{c}0.26 \\
(0.11-0.35) \\
\mathrm{a}\end{array}$ & $\begin{array}{c}0.27 \\
(0.14-0.37) \\
b\end{array}$ & $\begin{array}{c}0.15 \\
(0.12-0.18) \\
\mathrm{a}\end{array}$ \\
\hline $\begin{array}{l}\text { Respiration (mg } \mathrm{CO}_{2}{ }^{*} \mathrm{~g} \\
\text { dry soil day }{ }^{-1} \text { ) }\end{array}$ & $\begin{array}{c}0.04 \\
(0.03-0.09) \\
\mathrm{a}\end{array}$ & $\begin{array}{c}0.04 \\
(0.03-0.09) \\
\mathrm{ab}\end{array}$ & $\begin{array}{c}0.07 \\
(0.04-0.1) \\
\mathrm{b}\end{array}$ & $\begin{array}{c}0.05 \\
(0.02-0.07) \\
\mathrm{a} \\
\end{array}$ \\
\hline Moisture content (\%) & $\begin{array}{c}0.26 \\
(0.2-0.3) \\
\mathrm{a} \\
\end{array}$ & $\begin{array}{c}0.23 \\
(0.17-0.29) \\
\mathrm{ab} \\
\end{array}$ & $\begin{array}{c}0.24 \\
(0.2-0.3) \\
\mathrm{b}\end{array}$ & $\begin{array}{c}0.33 \\
(0.3-0.4) \\
\mathrm{c} \\
\end{array}$ \\
\hline Bulk density $\left(\mathrm{g}^{*} \mathrm{~cm}^{-3}\right)$ & $\begin{array}{c}1.2 \\
(1.1-1.3) \mathrm{a}\end{array}$ & $\begin{array}{c}1.21 \\
(1.1-1.3) \mathrm{a}\end{array}$ & $\begin{array}{c}1.2 \\
(1.1-1.3) \mathrm{a}\end{array}$ & $\begin{array}{c}1.1 \\
(1-1.2) b\end{array}$ \\
\hline MR $0-5\left(\mathrm{~kg} / \mathrm{cm}^{2}\right)$ & $\begin{array}{c}4.6 \\
(2.25-8.2) \mathrm{a}\end{array}$ & $\begin{array}{c}4.9 \\
(3-8) \\
\mathrm{ab}\end{array}$ & $\begin{array}{c}7.8 \\
(4.3-12.5) \\
b\end{array}$ & $\begin{array}{c}0.78 \\
(0-3) \\
\mathrm{c}\end{array}$ \\
\hline MR $5=10\left(\mathrm{~kg} / \mathrm{cm}^{2}\right)$ & $\begin{array}{c}6.5 \\
(3.5-10.8) \mathrm{a}\end{array}$ & $\begin{array}{c}7.6 \\
(4-11.5) \quad \mathrm{a}\end{array}$ & $\begin{array}{c}10 \\
(7-17) b\end{array}$ & $\begin{array}{c}2.6 \\
(0.8-5.5) \mathrm{c}\end{array}$ \\
\hline
\end{tabular}

